FINANCIAL RATIO ANALYSIS TO PREDICT THE FINANCIAL DISTRESS CONDITIONS OF PULP AND PAPER COMPANIES LISTED ON THE IINDONESIA STOCK EXCHANGE IN 2012-2017 WITH THE ALTMAN Z-SCORE MODEL

\title{
ANALISIS RASIO KEUANGAN UNTUK MEMPREDIKSI KONDISI FINANCIAL DISTRESS PERUSAHAAN PULP DAN KERTAS YANG TERDAFTAR DI BURSA EFEK INDONESIA TAHUN 2012-2017 DENGAN MODEL ALTMAN Z-SCORE
}

\author{
Maya Sari ${ }^{* 1}$ \\ Haugesti Diana
}

Sekolah Tinggi Ilmu Ekonomi Pelita Indonesia, Pekanbaru ${ }^{1}$

Universitas Islam Riau²

maya.sari746@yahoo.com ${ }^{1}$

haugestidiana@eco.uir.ac.id ${ }^{2}$

\begin{abstract}
Identification conditions of financial difficulties is more important than bankruptcy, because companies will surely experience financial distress conditions first and then go bankrupt. This studi aims to examine the effect of the Current Ratio (QR), Quick Ratio (QR), Debt to Equity Ratio (DER), Return On Assets (ROA), and sales growth on the financial distress conditions of the pulp and paper subsector companies listed on the indonesi stock exchange from 2012 to 2017. This study use a quantitative approach. The study population included all pulp and paper subsector companies listed on the Indonesia stock exchange from 2012 to 2017, namely 8 companies. The sample was determined by purpose sampling technique. Data analysis method used is logistic regression analysis. The results of thr study showed that the best performance of the company with the lowest level of bankruptcy was PT. Kedawung Setia Industrial Tbk. From the results of testing multiple linear regression obtained Roa has a significant effect on the condition of financial distress. Whereas $C R, Q R, D E R$ and Sales Growth do not effect the financial condition of the distress.
\end{abstract}

Keywords : $C R, Q R, D E R, R O A$, Financial Distress, pulp and paper subsector companies

\section{ABSTRACT}

Identifikasi kondisi financial distress merupakan hal yang lebih penting dari pada kebangkrutan, karena perusahaan pasti akan mengalami kondisi financial distress terlebih dahulu lalu kemudian bangkrut. Penelitian ini bertujuan untuk menguji pengaruh Current Ratio (CR), Quick Ratio (QR), Debt to Equity Ratio (DER), Return On Asset (ROA) dan pertumbuhan penjualan (sales growth) terhadap kondisi financial distress perusahaan subsektor pulp dan kertas yang terdaftar di Bursa Efek Indonesia tahun 2012-2017. Penelitian ini menggunakan pendekatan kuantitatif. Populasi penelitian meliputi seluruh perusahaan subsektor pulp dan kertas yang terdaftar di Bursa Efek Indonesia tahun 2012-2017 yaitu 8 perusahaan. Sampel ditentukan dengan teknik purpose sampling. Metode analisis data yang digunakan adalah analisis regresi logistik. Hasil penelitian menunjukkan bahwa kinerja perusahaan terbaik dengan tingkat kebangkrutan perusahaan terendah adalah PT. Kedawung Setia Industrial Tbk. Dari hasil pengujian regresi linear berganda diperoleh ROA berpengaruh signifikan terhadap kondisi financial distress. Sedangkan CR, QR, DER dan sales growth tidak berpengaruh signifikan terhadap kondisi financial distress.

Kata Kunci : CR, QR, DER, ROA, Financial Distress, Perusahaan Subsektor Pulp dan Kertas 


\section{Pendahuluan}

Kesehatan suatu perusahaan akan mencerminkan kemampuan dalam menjalankan usahanya, distribusi aktiva, penggunaan aktiva, hasil usaha yang telah dicapai,kewajiban yang harus dilunasi dan potensi kebangkrutan yang akan terjadi. Masalah keuangan yang dihadapi suatu perusahaan apabila dibiarkan berlarut-larut dapat mengakibatkan terjadinya kebangkrutan. Beberapa perusahaan yang mengalami masalah keuangan mencoba mengatasi masalah tersebut dengan melakukan pinjaman dan penggabungan usaha, atau sebaliknya ada yang menutup usahanya.

Financial distress atau kesulitan keuangan merupakan situasi dimana arus kas operasi tidak mencukupi untuk membiayai kewajiban sekarang yang ada seperti membayar hutang usaha atau membayar bunga, dan hal ini memaksa perusahaan untuk mengambil tindakan perbaikan. Kesulitan keuangan didefenisikan sebagai ketidakmampuan perusahaan untuk memenuhi kewajiban-kewajibannya/insolvency (Ross dan Jordan, 2008).

Model financial distress perlu untuk dikembangkan karena dengan mengetahui kondisi financial distressperusahaan sejak dini diharapkan dapat dilakukan tindakan-tindakan untuk mengantisipasi kondisi-kondisi yang mengarah kepada kebangkrutan. Banyak sekali literatur yang menggambarkan model prediksi kebangkrutan perusahaan, tetapi hanya sedikit penelitian yang berusaha untuk memprediksi financial distress suatu perusahaan. Hal ini dikarenakan sangat sulit untuk mendefenisikan secara objektif permulaan adanya financial distress.

Alasan peneliti memilih objek penelitian perusahaan pulp dan kertas adalah karena penelitian yang dilakukan disektor perusahaan manufaktur khususnya industry pulp dan kertas ini masih sangat jarang dilakukan, sedamgkan industry ini sangat rentann diterpa oleh isu negatife tentang dampak buruknya terhadap social dan lingkungan. Disamping itu pula pertumbuhan usaha dibidang industry ini dibilang pesat karena permintaan konsumsi terhadap kertas dari masyarakat semakin meningkat dari tahun ketahun. Beberapa permasalahan pencemaran dan polusi, kerusakan lingkungan dan terancamnya kelestarian.

Ketatnya persaingan antar perusahaan pulp dan kertas dalam negeri berikut isu global mengenai sosial dan lingkungan yang semakin menjadi fokus industri dinilai cukup dasyat mempengaruhi kinerja industri tersebut. Meskipun pertumbuhan ekonomi mendorong pasar domestik memberikan peluang usaha, hal ini dilemahkan dengan keterkaitan industri pulp dan kertas dengan isu kelestarian lingkungan yang kerap dihembuskan kritik dan tudingan negatif yang kurang menggembirakan.

Selain itu, industri pulp dan kertas merupakan salah satu industri yang mempunyai peranan penting dan merupakan produk unggulan dalam menunjang perekonomian indonesia. Pertumbuhan industri pulp dan kertas yang pesat memungkin kan bermunculannya perusahaan-perusahaan besar yang memiliki modal yang kuat dan berskala besar. Produk industri kehutanan sangat besar peranannya dalam pembangunan ekonomi bukan saja sebagai penyedia lapangan kerja akan tetapi juga merupakan salah satu penyumbang devisa yang cukup penting dan potensial bagi penerimaan negara dari sektor non migas.

Tabel 1. Rata-rata laba perusahaan pulp dan kertas selama periode 2012-2017 (dalam jutaan rupiah)

\begin{tabular}{lllllll}
\hline Tahun & 2012 & 2013 & 2014 & 2015 & 2016 & 2017 \\
\hline $\begin{array}{l}\text { rata- } \\
\text { rata }\end{array}$ & 25,585 & 375 & 42,910 & 133,360 & 196,642 & 148,515 \\
\hline
\end{tabular}

Sumber : Bursa Efek Indonesia (diolah)

Terlihat pada tabel diatas bahwa pertumbuhan penjualan sub sektor pulp dan kertas pada tahun 2012 sebesar 25,585, 2013 sebesar 375, 2014 sebesar 42,910, 2015 sebesar 133,360, 2016 sebesar 196,642 dan pada tahun 2017 sebesar 148,515 dari tahun ketahun 
mengalami peningkatan. Hal ini disebabkan konsumsi masyarakat terhadap kertas semakin meningkat dan semakin banyak perusahaan yang bergerak dibidang yang sama.

Untuk menilai kinerja keuangan perusahaan biasanya menggunakan analisis rasio keuangan. Alasan penggunaan rasio keuangan karena rasio keuangan memiliki peranan yang sangat penting dalam evaluasi kinerja keuangan dan dapat juga digunakan untuk memprediksi kelangsungan hidup suatu perusahaan apakah perusahaan tersebut dalam keadaan yang sehat atau tidak sehat bahkan kemungkinan dalam kebangkrutan (Chen,1981 dalam Susanti (2013:11)).

Adapun analisis kebangkrutan yang sering digunakan untuk melihat suatu kebangkrutan dalam suatu perusahaan ada tiga analisis yang digunakan yakni Z-Score Model Altman, Model Springate dan Model Zmijewski. Analisis kebangkrutan tersebut karena selain caranya mudah, keakuratan dalam menentukan prediksi kebangkrutannya pun cukup akurat. Dalam penelitian ini analisis yang digunakan yaitu model Altman Z-Score. Hal yang menarik tentang Z-Score adalah keandalannya sebagai alat analisis tanpa memperhatikan bagaimana ukuran perusahaan. Meskipun, seandainya perusahaan sangat makmur, bila Z-Score menunjukkan nilai yang kurang baik, maka perusahaan harus berhati-hati. Bila perusahaan memiliki kinerja keuangan yang sehat maka perlu diwaspadai karena resiko tinggi menuju kebangkrutan.

Berdasarkan dari uraian latar belakang diatas, maka tujuan dari penelitian ini adalah untuk menguji pengaruh rasio keuangan yang terdiri dari current ratio, quick ratio, debt to equity, return on asset dan sales growth terhadap kondisi financial distress perusahaan pulp dan kertas yang terdaftar di Bursa Efek Indonesia tahun 2012-2017.

\section{Tinjauan Pustaka}

\section{Pengertian Analisis Laporan Keuangan}

Harahap (2007:190) mengungkapkan analisis laporan keuangan berarti menguraikan pos-pos laporan keuangan menjadi unit informasi menjadi unit informasi yang lebih kecil dan melihat hubungannya yang bersifat signifikan atau yang mempunyai antara satu dengan yang lain baik antara kuantitatif maupun data non-kuantitatif dengan tujuan untuk mengetahui kondisi keuangan yang lebih dalam yang sangat penting dalam proses menghasilkan keputusan yang tepat.

Menurut Kasmir (2008:7) yang dimaksud laporan keuangan adalah yang menunjukkan kondisi keuangan perusahaan saat ini atau dalam suatu periode tertentu. Sedangkan menurut Harahap (2011:190) mengungkapkan analisis laporan keuangan berarti menguraikan pos-pos laporan keuangan menjadi unit informasi menjadi unit informasi yang lebih kecil dan melihat hubungannya yang bersifat signifikan atau yang mempunyai antara satu dengan yang lain baik antara kuantitatif maupun data non-kuantitatif dengan tujuan untuk mengetahui kondisi keuangan yang lebih dalam yang sangat penting dalam proses menghasilkan keputusan yang tepat.

Menurut Kasmir (2008:66), tujuan utama analisis keuangan adalah: agar dapat mengetahui posisi keuangan saat ini. Dengan mengetahui posisi keuangan, setelah dilakukan analisis laporan keuangan secara mendalam, akan terlihat apakah perusahaan dapat mencapai target yang telah direncanakan sebelumnya atau tidak. Hasil analisis laporan keuangan akan memberikan informasi tentang kekuatan dan kelemahan perusahaan. Dengan adanya kelemahan dan kekuatan yang dimiliki maka akan tergambar kinerja perusahaan.

\section{Financial Distress}

Menurut Plat dan Plat dalam Fahmi (2011:158) mendefenisikan financial distresss sebagai tahap penurunan kondisi keuangan yang terjadi sebelum terjadinya kebangkrutan ataupun likuidasi. Financial distress dimulai dengan ketidakmampuan memenuhi kewajiban- 
kewajibannya, terutama kewajiban yang bersifat jangka pendek termasuk kewajiban likuiditas, dan juga termasuk kewajiban dalam kategori solvabilitas.

Menurut (Indri, 2012:103) Financial distress adalah suatu situasi dimana arus kas operasi perusahaan tidak memadai untuk melunasi kewajiban-kewajiban lancar (seperti hutang dagang atau beban bunga) dan perusahaan terpaksa melakukan tindakan perbaikan.

Apabila ditinjau dari aspek keuangan perusahaan (financial factor) maka terdapat tiga keadaan yang dapat menyebabkan perusahaan mengalami financial distress (Suciati,2008:6):

Pertama, faktor ketidakmampuan modal atau kekurangan dana. Terjadinya ketidakseimbangan aliran penerimaan uang yang bersumber pada penjualan atau penagihan piutang dengan pengeluaran uang untuk membiayai operasi perusahaan, akan menimbulkan persoalan kekurangan dana. Apabila perusahaan tidak mampu menarik dana untuk memenuhi kekurangan dana tersebut, maka perusahaan akan berada pada kondisi tidak likuid.

Kedua, besarnya beban hutang dan bunga. Apabila perusahaan mampu menarik dana dari luar misalnya mendapatkan kredit dari bank untuk menutup kekurangan dana, maka masalah likuiditas perusahaan dapat teratasi untuk sementara waktu. Tetapi kemudian timbul persoalan baru yaitu adanya keterkaitan kewajiban untuk membayar kembali pokok pinjaman dan bunga kredit. Walaupun demikian keadaan ini tidak membahayakan perusahan dan masih memberikan keuntungan bagi perusahaan, apabila tingkat bunga lebih rendah dari tingkat investasi harta (return on asset) dan perusahaan melakukan apa yang disebutkan manajemen resiko atas hutang yang diterimanya. Ketidakmampuan perusahaan untuk melakukan manajemen resiko atas hutangnya dapat mengakibatkan perusahaan harus mendapatkan resiko menderita kerugian yang seharusnya tidak perlu terjadi yang pada akhirnya timbul penyitaan yang dijadikan sebagai jaminan pada bank.

Ketiga, menderita kerugian. Pendapatan yang diperoleh perusahaan harus mampu menutup seluruh biaya yang dikeluarkan dan menghasilkan laba bersih. Besarnya laba bersih sangat penting bagi perusahaan untuk melakukan reinvestasi, sehingga akan menambah kekayaan bersih perusahaan dan akan meningkatkan ROE(return on equity) untuk menjamin kepentingan pemegang saham. Oleh karena itu perusahaan harus selalu berupaya meningkatkan pendapatan dan meningkatkan tingkat biaya ketidakmampuan perusahaan mempertahankan keseimbangan pendapatan dengan biaya niscaya perusahaan akan menderita kerugian dan perusahaan akan mengalami financial distress.

Permasalahan keuangan (financial distress) sudah menjadi momok bagi seluruh perusahaan, karena permasalahan keuangan dapat menyerang seluruh jenis perusahaan walaupun perusahaan yang bersangkutan adalah perusahaan yang besar. Peliknya permasalahan keuangan pada perusahaan ini menjadi bahan yang menarik untuk diteliti karena banyak perusahaan berusaha untuk menghindari permasalahan ini. Selain itu, permasalahan keuangan memiliki pengaruh yang besar, dimana bukan hanya pihak perusahaan yang mengalami kerugian, tetapi juga stakeholder dan shareholder perusahaan juga akan terkena dampaknya.

\section{Model Altman Z-score}

Model Altman Z-Score merupakan Multiple Disriminant Analysis yang dilakukan oleh Altman yaitu analisis Z-Score dimana formula Z-Score dalam memprediksi kebangkrutan dari Altman merupakan formula multi-variate yang digunakan untuk mengukur kesehatan finansial suatu perusahaan.

Altman terus melakukan penelitian dan perkembangan terhadap Z-Score, berikut ini perkembangan model Altman (Prihadi, 2010; 336-339) yang terdiri dari Model Altman Z-Score Asli, Model Altman Z'-Score dan Model Altman Z"-Score. 


\section{Model Altman Original}

Pada model pertama ini, Altman melakukan penelitian dengan kondisi sampel perusahaan diambil dari perusahaan publik manufaktur yang berlokasi di Amerika sebanyak 66 perusahaan baik dalam kondisi bangkrut dan tidak bangkrut dan jumlah rasio yang diuji adalah sebanyak 22 rasio. Dari hasil penelitiannya, Altman merumuskan Altman Z-Score dengan menggunakan 5 rasio yang memiliki pengaruh yang paling kuat dan secara bersama berkorelasi dengan kebangkrutan. Menurut (Ramadhani dan Lukviarman,2009:21) Berikut rumus Altman Z-Score original :

$Z=1,2 \mathrm{X}_{1}+1,4 \mathrm{X}_{2}+3,3 \mathrm{X}_{\mathrm{a}}+0,6 \mathrm{X}_{4}+1,0 \mathrm{X}_{5}$

Dengan nilai cut-off :

$\begin{array}{rll}\text { Z } & <1,81< & \text { Bangkrut } \\ Z & <2,99 & \text { Grey Area } \\ \text { Z } & >2,99 & \text { Tidak Bangkrut }\end{array}$

Dimana:

$Z \quad=$ Z-Score Index

$\mathrm{X} 1$ = Current Ratio

$\mathrm{X} 2$ = Quick Ratio

$\mathrm{X} 3=$ Debt to Equity

$\mathrm{X} 4=$ Return On Asset

$\mathrm{X} 5=$ sales growth

\section{Modifikasi Altman Z-Score}

Untuk mengantisipasi kelemahan dari formula asli Altman Z-Score, ada beberapa solusi yang ditawarkan. Untuk perusahaan pribadi, tidak bisa dilakukan perhitungan Market Value of Equity. Oleh karena itu dilakukan perbaikan formal sebagai berikut:

$$
Z=0.717 X_{1}+0.847 X_{2}+3.107 X_{3}+0.42 X_{4}+0.998 X_{5}
$$

Value of equity/liabilities. Sedangkan penafsiran hasil Z-Score yang didapatkan adalah sebagai berikut:

Z-Score . 2,90 : Dapat disimpulkan bahwa perusahaan tersebut tidak mengalami kesulitan dalam keuangan sehingga perusahaan ini dalam kategori tidak bangkrut atau aman.

Z-Score 1,23 <_ Z-Score < 2,9 : Dapat disimpulkan bahwa perusahaan tersebut tidak dapat diprediksikan bangkrut atau tidak ini disebut juga kategori grey area (abu-abu).

Z-Score 1,23 : Dapat disimpulkan bahwa perusahaan tersebut mengalami kesulitan dalam keuangan sehingga perusahaan termasuk kategori bangkrut.

Sedangkan untuk perusahaan yang tidak terdaftar di Bursa Efek Indonesia menggunakan formula sebagai berikut:

$$
Z=6.56 X_{1}+3.26 X_{2}+6.72 X_{3}+1.05 X_{4}
$$

X5 dihilangkan untuk menghilangkan bias assets turnover.

Penafsiran hasil Z-Score adalah sebagai berikut:

Jika Z-Score> 2.60 : Dapat diprediksikan bahwa perusahaan tersebut dalam kategori aman atau tidak bangkrut.

Jika 1,1 < Z-Score $<2,60$ : Maka dapat diprediksikan bahwa perusahaan tersebut dalam kategori grey area (abu-abu). 
Jika Z $<1,1$ : Maka dapat diprediksikan bahwa perusahaan tersebut mengalami kesulitan dalam keuangan sehingga perusahaan ini termasuk kategori bangkrut.

\section{Analisis Rasio Keuangan}

Analisis rasio (ratio analysis), adalah evaluasi yang terjadi antara berbagai variabel dalam laporan keuangan. Perusahaan dapat menilai karakteristik keuangannya dengan membandingkan antara rasio keuangan yang dimilikinya dan rasio keuangan perusahaanperusahaan lain dalam industri yang sama. Sehingga perusahaan dapat mengetahui bagaimana perbedaan kondisi keuangannya jika dibandingkan dengan perusahaan-perusahaan lain yang melakukan jenis bisnis yang sama (Madura, 2007:356).

\section{Current Ratio (CR)}

Rasio ini digunakan untuk mengukur kemampuan perusahaan dalam membayar kewajiban lancarnya dengan menggunakan aset lancar yang dimiliki perusahaan. Dari hasil pengukuran rasio, apabila hasil rasio ini rendah menandakan perusahaan kurang modal untuk membayar kewajibannya. Namun apabila hasil rasio ini tinggi belum tentu kondisi perusahaan sedang baik karena kas tidak digunakan sebaik mungkin. Menurut Kasmir (2008:135) seringkali dipakai bahwa rasio lancar dengan standar 200\% (2:1) dianggap sebagai ukuran yang cukup baik bagi perusahaan, artinya setiap 1 rupiah hutang lancar sudah tercover oleh 2 rupiah aktiva lancar. Berdasar kan penelitian yang dilakukan oleh (Haq 2013) mengatakan Curent ratio berpengaruh terhadap kemungkinan terjadinya financial distress pada perusahaan yang terdaftar di BEl.

$\mathrm{H}_{1}$ : Variabel Current Ratio berpengaruh signifikan terhadapkondisi financial distress.

\section{Quick Ratio (QR)}

Quick ratio merupakan ukuran kemampuan perusahaan dalam memenuhi jangka pendeknya dengan tidak menghitungkan persediaan, karena persediaan biasanya dianggap merupakan aset yang tidak likuid. Quick ratio disebut juga acid test ratio, merupakan pertimbangan antara jumlah aktiva lancar dikurangi persediaan, dengan jumlah hutang lancar. Persediaan tidak dimasukkan dalam perhitungan quick ratio karena persediaan merupakan komponen aktiva lancar yang paling kecil tingkat likuiditasnya. Menurut Setiawan (2009) yang mengatakan bahwa quick ratio berpengaruh negatif terhadap kondisi financial distress perusahaan $\mathrm{H}_{2}$ : Variabel Quick Ratio berpengaruh signifikan terhadap kondisi financial distress.

\section{Debt to Equity Ratio (DER)}

Debt to Equity Ratio merupakan salah satu rasio keuangan yang tergolong kelompok rasio solvabilitas. Debt to Equity Ratio adalah rasio yang menggunakan hutang dan modal untuk mengukur besarnya rasio. Debt to Equity Ratio merupakan rasio yang dipergunakan untuk mengukur tingkat penggunaan utang terhadap total shareholder's equity yang dimiliki perusahaan. Penelitian yang dilakukan oleh Iman dan Srengga (2012) yang menunjukkan bahwa Debt To Equity tidak berpengaruh signifikan terhadap kondisi financial distress, namun hal ini bertolak belakang dengan penelitian yang dilakukan oleh Simanjuntak, Titik, dan Aminah (2017) yang menunjukkan bahwa Debt To Equity mempunyai pengaruh signifikan terhadap kondisi financial distress.

$\mathrm{H}_{3}$ : Variabel Debt to Equity Ratioberpengaruh signifikan terhadapkondisi financial distress.

\section{Return On Asset (ROA)}

Return On Asset adalah rasio profitabilitas yang menunjukan persentase keuntungan (laba bersih) yang diperoleh perusahaan sehubungan dengan keseluruhan sumber daya atau ratarata jumlah aset. Dengan kata lain, Return on Asset atau sering disingkat dengan ROA adalah rasio yang mengukur seberapa efisien suatu perusahaan dalam mengelola asetnya untuk menghasilkan laba selama suatu periode.Menurut Indriyati (2010) yang menyimpulkan bahwa 
variabel ROA mempunyai pengaruh signifikan terhadap Altman Z-Score. Dan menurut Furqon (2012) mengatakan return on asset dapat digunakan untuk memprediksi terjadinya kondisi financial distress perusahaan.

$\mathrm{H}_{4}$ : Variabel Return On Asset berpengaruh signifikan terhadapkondisi financial distress.

\section{Pertumbuhan Penjualan (Sales Growth)}

Menurut Hapsari (2012) menyatakan bahwa sales growth adalah kenaikan jumlah penjualan dari tahun ketahun atau dari waktu ke waktu. Pertumbuhan penjualan tinggi, maka akan mencerminkan pendapatan perusahaan yang juga meningkat.Penelitian yang dilakukan oleh Widarjo dan Setiawan (2009) menyatakan bahwa sales growth tidak berpengaruh terhadap financial distress perusahaan. Sedangkan Furqon (2012) menyatakan bahwa sales growth dapat digunakan untuk memprediksi terjadinya kondisi financial distress perusahaan.

$\mathrm{H}_{5}$ : Variabel Pertumbuhan Penjualanberpengaruh signifikan terhadapkondisi financial distress.

\section{Kerangka Pemikiran}

Penelitian ini menggunakan rasio keuangan Current Ratio (CR), Quick Ratio (QR), Return On Asset (ROA), Debt to Equity (DER), dan Pertumbuhan Penjualan (sales growth) yang digunakan untuk menilai kinerja perusahaan yang mengalamifinancial distress.Berdasarkan landasan teori, pengaruh antar variabel dan hasil penelitian sebelumnya maka untuk merumuskan hipotesis, berikut disajikan dengan kerangka pemikiran yang dituangkan dalam model penelitian pada gambar $1 \mathrm{sbb}$ :

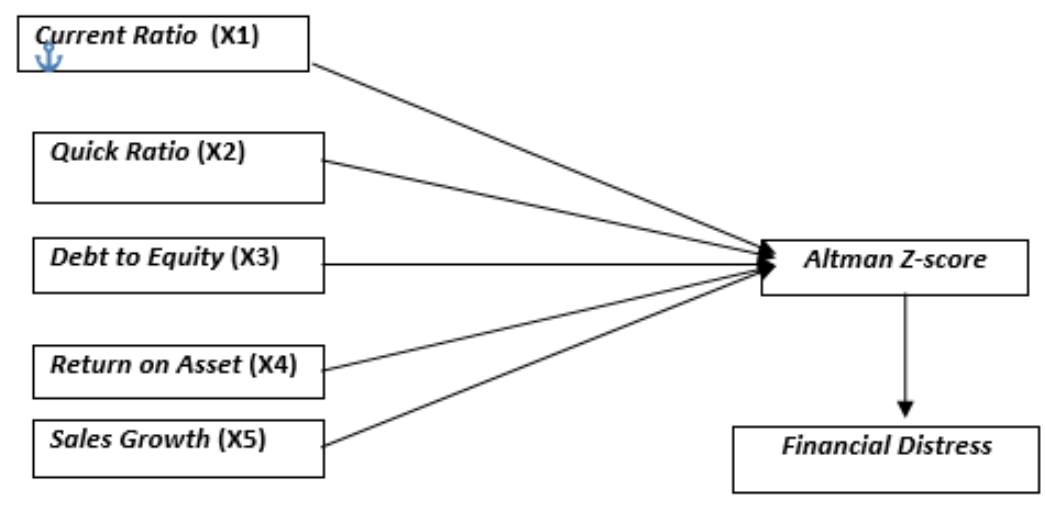

Gambar 1. Kerangka Pemikiran

\section{Metode Penelitian}

\section{Tempat dan Waktu Penelitian}

Penelitian ini dilakukan pada perusahaan pulp dan kertas yang terdaftar di Bursa Efek Indonesia tahun 2012-2017, sedangkan waktu penelitian dilakukan dari bulan Agustus 2018Februari 2019.

\section{Sampel Penelitian}

Sampel dalam penelitian ini adalah perusahaan pulp dan kertas go public yang terdaftar di Bursa Efek Indonesia (BEI) sebanyak 8 perusahaan. Metode pengambilan sampel yang digunakan adalah purpose sampling yaitu pemilihan sampel perusahaan manufaktur sub sektor pulp dan kertas selama periode penelitian menetapkan berdasarkan pertimbangannya 
dari sampel penelitian,sehingga teknik pengambilan sampel purpose sampling ini didasarkan pada kelengkapan laporan keuangan yang dibutuhkan untuk memenuhi rasio-rasio yang dibutuhkan dalam analisis model Altman Z-Score.

Tabel 2. Sampel Perusahaan Pulp dan Kertas yang terdaftar di BEI

\begin{tabular}{lll}
\hline NO & Kode Saham & Nama Emiten \\
\hline 1 & ALDO & PT. Alkindo Naratama Tbk \\
\hline 2 & FASW & PT. Fajar Surya Wisesa Tbk \\
\hline 3 & INKP & PT. Indah Kiat Pulp \& Paper Tbk \\
\hline 4 & INRU & PT. Toba Pulp Lestari Tbk \\
\hline 5 & KBRI & PT. Kertas Basuki Rachmat Indonesia Tbk \\
\hline 6 & KDSI & PT. Kedawung Setia Industrial Tbk \\
\hline 7 & SPMA & PT. Suparma Tbk \\
\hline 8 & TKIM & PT. Pabrik Kertas Tjiwi Kimia Tbk \\
\hline
\end{tabular}

Sumber : $\underline{w w w . i d x . c o . i d}$ (diolah)

\section{Variabel Independen}

Rasio Lancar (Current Ratio)merupakan rasio yang menunjukkan kemampuan perusahaan dalam memenuhi liabilitas jangka pendeknya.

Current Ratio $=\frac{\text { Current Asset }}{\text { Current Liabilities }}$

Rasio Cepat (Quick Ratio) merupakan rasio yang mencerminkan kemampuan perusahaan memenuhi liabilitas lancar dengan menggunakan aset lancar dengan persediaan tidak dimasukkan sebagai bagian dari pembilang karena persediaan mungkin tidak dapat diubah menjadi kas dengan mudah.

Quick Ratio $=\frac{\text { Current Ratio }- \text { Inventory }}{\text { Current Liabilities }}$

Rasio Hutang Terhadao Ekuitas (Debt to Equity Ratio) merupakan rasio yang membandingkan jumlah hutang terhadap ekuitas.

$D E R=\frac{\text { Total Hutang }}{\text { Modal (Equity) }}$

Rasio Tingkat Pengembalian atas Aktiva (Return on Assets) merupakan rasio yang mengukur pengembalian perusahaan sebagai persentase dari total jumlah aktiva yang dimanfaatkan oleh perusahaan.

ROA $=\frac{\text { Net Income After Tax (NIAT) }}{\text { Total Aktiva }}$

Rasio Pertumbuhan Penjualan (Sales Growth) merupakan rasio yang mengukur seberapa besar kemampuan perusahaan dalam mempertahankan posisinya didalam industri dan dalam perkembangan ekonomi secara umum. 
Pertumbuhan Penjualan $=\frac{\text { Penjualan tahun }_{\mathrm{t}}-\text { Penjualan }_{\text {tahun }} \mathrm{t}-1}{\text { Penjualan tahun }_{\mathrm{t}-1}}$

\section{Teknik Pengumpulan Data}

Dalam Penelitian ini pengumpulan data dilakukan dengan metode dokumentasi dengan menelusuri data perusahaan yang terdapat pada Bursa Efek Indonesia berupa laporan keuangan neraca dan laba rugi pada tahun 2012-2017.

\section{Teknik Analisis Data}

\section{Altman Z-Score}

Dalam penelitian ini,analisis kebangkrutan yang akan digunakan yaitu analisis Altman Z-Score, analisis Altman Z-Score menggunakan laporan keuangan sebagai alat prediksi terhadap kemungkinan bangkrut atau tidaknya perusahaan. Data atau hasil perhitungan dapat dilihat dari nilai Z-Scorenya dengan rumus (Ramadhani dan Lukviarman, 2009:21) :

$Z=1.2 X_{1}+1.4 X_{2}+3.3 X_{3}+0.6 X_{4}+1.0 X_{5}$

Dimana :

$Z \quad=$ Z-Score Index

$\mathrm{X} 1=$ Current Ratio

$\mathrm{X} 2$ = Quick Ratio

$\mathrm{X} 3=$ Debt to Equity

$\mathrm{X} 4=$ Return On Asset

$\mathrm{X} 5$ = sales growth

Hasil perhitungan terhadap nilai Z tersebut adalah,jika :

Jika $Z<1,88$ : perusahaan mengalami kebangkrutan.

Jika $1,8<Z<2,99$ : perusahaan akan mengalami ancaman kebangkrutan atau dapat dikategorikan grey area.

Jika Z > 2,99 : perusahaan tidak mengalami kebangkrutan.

\section{Uji Asumsi Klasik}

Menurut Adisasmita (2008:36) sebelum melakukan analisis data sebaiknnya dimulai dari pengujian normalitas data untuk mendeteksi distribusi data dalam variabel serta juga dilakukan pengujian statistik untuk mengetahui apakah hasil estimasi regresi yang dilakukan betul-betul terbebas dari gejala multikolinearitas, autokorelasi dan heterodastisitas.

\section{Uji Regresi Berganda}

Analisis regresi berganda (Multiple Regresion Technic) yang digunakan untuk menentukan pengaruh antara variabel independen (current ratio, quick ratio, debt to equity, return on assets dan sales growth) terhadap variabel dependen yaitu nilai Z-Score untuk mengetahui pengaruh rasio keuangan terhadap tingkat kebangkrutan dalam metode Altman Z-Score dimana dinyatakan dalam persamaan berikut :

$Y=a+b_{1} X_{1}+b_{2} X_{2}+b_{3} X_{3}+b_{4} X_{4}+b_{5} X_{5}$ 
Keterangan:

$\mathrm{Y}=\mathrm{Z}$-Score

$\mathrm{a}=$ konstanta

b $(1, \ldots, 9)=$ koefisien regresi

$\mathrm{X}_{1}=$ current ratio

$\mathrm{X}_{2}=$ quick ratio

$\mathrm{X}_{3}=$ debt to equity ratio

$\mathrm{X}_{4}=$ return on asset ratio

$\mathrm{X}_{5}=$ sales growth

\section{Uji Koefisien Determinasi}

Koefisien determinasi pada intinya mengukur seberapa jauh kemampuan model dalam menerangkan variasi variabel dependen (Ghozali, 2009). Dengan menggunakan uji koefisien determinasi dapat diketahui seberapa jauh suatu variabel bebas menentukan perubahan nilai variabel terikat. Besarnya koefisien determinasi terletak antara satu dan nol.Apabila dirumuskan nilai koefisien determinasi adalah :

$$
r^{2}=1-\frac{\Sigma\left(Y-Y^{s}\right)^{2}}{\sum(Y-\bar{Y})^{2}}
$$

Dimana $r^{2}$ adalah nilai koefisien determinasi, $\Sigma\left(Y-Y^{\prime}\right)^{2}$ adalah jumlah keseluruhan selisih antara variabel terikat terhadap garis regresi dan $\Sigma(Y-\bar{Y})^{2}$ merupakan jumlah keseluruhan antara variabel terikat terhadap rata-rata variabel terikat.

\section{Uji Statistik F}

Uji $\mathrm{F}$ digunakan untuk menguji pengaruh variabel independen secara bersama berpengaruh atau tidak berpengaruh signifikan terhadap variabel dependen.

Jika $F_{\text {hitung }}>F_{\text {tabel }}$ maka $\mathrm{H}_{0}$ ditolak yang berarti $X_{1}(C R), X_{2}(Q R), X_{3}(D E R), X_{4}(R O A), X_{5}$ (Sales Growth) secara simultan berpengaruh terhadap $Y$ (Financial Distress). Sedangkan, apabila $F_{\text {hitung }}<F_{\text {tabel }}$ maka $H_{0}$ ditolak yang berarti $X_{1}(C R), X_{2}(Q R), X_{3}(D E R), X_{4}(R O A), X_{5}$ (Sales Growth)secara simultan tidak berpengaruh terhadap $Y$ (Financial Distress).

\section{Uji Statistik t}

Uji t digunakan untuk menguji pengaruh variabel independen secara parsial berpengaruh atau tidak berpengaruh signifikan terhadap variabel dependen.

Jika $t_{\text {hitung }}>t_{\text {tabel }}$ maka $H_{0}$ ditolak yang berarti $X_{1}(C R), X_{2}(Q R), X_{3}(D E R), X_{4}(R O A), X_{5}$ (Sales Growth) secara parsial berpengaruh terhadap $Y$ (Financial Distress). Sedangkan, apabila $t_{\text {hitung }}<t_{\text {tabel }}$ maka $\mathrm{H}_{0}$ ditolak yang berarti $X_{1}(C R), X_{2}(Q R), X_{3}(D E R), X_{4}(R O A), X_{5}$ (Sales Growth), secara parsial tidak berpengaruh terhadap $Y$ (Financial Distress).

\section{HASIL DAN PEMBAHASAN}

\section{Analisis Deskriptif}

Tabel 3. Statistik Deskriptif

\begin{tabular}{llllllll}
\hline \multirow{2}{*}{ No. } & \multirow{2}{*}{ Variabel } & \multicolumn{2}{l}{ Rata-Rata } & & & & \\
\cline { 2 - 7 } & & $\mathbf{2 0 1 2}$ & $\mathbf{2 0 1 3}$ & $\mathbf{2 0 1 4}$ & $\mathbf{2 0 1 5}$ & $\mathbf{2 0 1 6}$ & $\mathbf{2 0 1 7}$ \\
\hline 1 & Current Ratio (CR) & 161,02 & 140,81 & 167,54 & 114,48 & 129,18 & 121,93 \\
2 & Quick Ratio (QR) & 0,89 & 0,99 & 0,94 & 0,71 & 0,71 & 0,72 \\
3 & Debt to Equity Ratio (DER) & 1,43 & 1,53 & 1,59 & 1,71 & 1,45 & 1,58 \\
4 & Return on Assets (ROA) & 2,76 & 0,88 & 2,18 & $-0,92$ & 3,97 & 3,12
\end{tabular}




\begin{tabular}{llllllll}
\hline & & & & & \\
5 & Sales Growth & 0,11 & 0,05 & 0,58 & 0,80 & 0,00 & 0,14 \\
8 & Z"-Score Altman (Z") & 1,69 & 1,07 & 1,16 & 0,79 & 0,99 & 0,01 \\
\hline No. & \multirow{2}{*}{ Nama Perusahaan } & \multicolumn{7}{l}{ KriteriaKebangkrutan } \\
\cline { 3 - 7 } & & $\mathbf{2 0 1 2}$ & $\mathbf{2 0 1 3}$ & $\mathbf{2 0 1 4}$ & $\mathbf{2 0 1 5}$ & $\mathbf{2 0 1 6}$ & $\mathbf{2 0 1 7}$ \\
\hline 1 & PT. Alkindo Naratama Tbk & TB & GA & GA & GA & GA & GA \\
2 & PT. Fajar Surya Wisesa Tbk & B & B & B & B & B & B \\
3 & PT. Indah Kiat Pulp \& Paper Tbk & B & B & B & B & B & B \\
4 & PT. Toba Pulp Lestari Tbk & B & B & B & B & B & B \\
& PT. Kertas Basuki Rachmat Indonesia & & & & & & \\
5 & Tbk & GA & B & B & B & B & B \\
6 & PT. Kedawung Setia Industrial Tbk & TB & GA & GA & GA & GA & GA \\
7 & PT. Suparma Tbk & GA & B & GA & B & B & GA \\
8 & PT. Pabrik Kertas Tjiwi Kimia Tbk & B & GA & B & B & B & B \\
\hline
\end{tabular}

Sumber: www.idx.co.id (diolah)

Dari tabel 3. diatas, dapat dilihat tingkat likuiditas perusahaan dari rata-rata CR perusahaan pulp dan kertas dari tahun ke tahun mengalami fluktuatif merata dimana tahun 2015 memiliki rata-rata CR terendah. Rata-rata CR tertinggi pada tahun 2014 sebesar 167,54. Sedangkan Rata-rata QR tahun ke tahun mengalami fluktuatif merata. Rata-rata QR terendah sebesar 0,71ditahun 2015 dan 2016 dan rata-rata QR tertinggi di tahun 2013 sebesar 0,99. Tingkat efisiensi operasi perusahaan dari rata-rata DER perusahaan pulp dan kertas dari tahun ke tahun mengalami fluktuatif merata, Rata-rata DER terendah sebesar 0,43 ditahun 2012dan rata-rata DER tertinggi sebesar 1,71 ditahun 2015 . Sedangkan rata-rata ROA perusahaan pulp dan kertas terendah pada tahun 2015 sebesar $-0,92$ dan rata-rata ROA tertinggi pada tahun 2016 sebesar 3,97. Lalu sales growth perusahaan pulp dan kertas dari tahun 2016 mengalami penurunan yaitu sebesar 0,00 dan mengalami peningkatan pada tahun 2015 yaitu sebesar 0,80 .

\section{Hasil Uji Regresi}

Untuk melihat seberapa besar $C R, Q R, R O A, D E R$, Sales Growth, Altman Z-score Hasil uji Regresi Linier Berganda dapat dilihat pada tabel sebagai berikut:

Tabel 4. Hasil Uji Regresi

\begin{tabular}{llllll}
\hline \multirow{2}{*}{ Model } & \multicolumn{2}{l}{$\begin{array}{l}\text { Unstandardized } \\
\text { Coeffcients }\end{array}$} & $\begin{array}{l}\text { Standardized } \\
\text { Coeffcients }\end{array}$ & Sig & VIF \\
\cline { 2 - 6 } & $\mathrm{B}$ & Std.Error & Beta & & \\
\hline (Counstant) & 0,580 & 0,453 & & & \\
$C R\left(\mathrm{X}_{1}\right)$ & 0,000 & 0,002 & 0,035 & 0,883 & 1.803 \\
$Q R\left(\mathrm{X}_{2}\right)$ & 0,553 & 0,332 & 0,275 & 0,104 & 1.819 \\
$D E R\left(\mathrm{X}_{3}\right)$ & $-0,092$ & 0,209 & $-0,062$ & 0,661 & 1.294 \\
$R O A\left(\mathrm{X}_{4}\right)$ & 0,080 & 0,026 & 0,446 & 0,004 & 1.42 \\
Sales_Growth $\left(\mathrm{X}_{5}\right)$ & 0,000 & 0,118 & 0,000 & 0,996 & 1.126 \\
\hline Durbin-Watson & $\mathbf{0 , 0 7 7}$ & & & & \\
Adj $\boldsymbol{R}$-Square & $\mathbf{0 , 2 9 7}$ & & & & \\
Sig. (F-test) & $\mathbf{2 , 4 4}$ & & & & \\
\hline
\end{tabular}

Sumber: data olahan (2019) 
Setelah dilakukan pengujian, hasil uji asumsi yang dilakukan untuk uji normalitas data dari grafik menyatakan data normal dan hasil uji heterokedastisitas dari grafik, semua titik menyebar dan tidak membentuk pola tertentu. Dari pengujian grafik dinyatakan model regresi dapat digunakan dalam penelitian.

Sedangkan dari hasil uji statistik yaitu uji multikoliniaritas yang diuji menggunakan coefficient variance inflation factor (VIF), seluruh variabel independen (CR, QR,DER,ROA dan Sales Growth)) memiliki VIF dibawah 10. Dari hasil uji run test, data tidak bersifat random karena nilai signifikan berada dibawah 0,05 dan dari hasil uji autokorelasi dari nilai DurbinWatson, data tidak dapat diputuskan ada atau tidak adanya autokorelasi karena nilai DW berada diantara $\mathrm{dL}$ dan $\mathrm{dU}$ :

$$
\begin{gathered}
\mathrm{dL}<\mathrm{DW}<\mathrm{dU} \\
2,7457<\quad 0,077<2,2186
\end{gathered}
$$

Memperhatikan hasil uji regresi pada tabel 4. diatas, diperoleh nilai konstanta $(\beta 0)$ dari model regresi adalah 0,580 dan koefisien regresi $(\beta i)$ dari setiap variabel-variabel independen diperoleh masing-masing untuk $\beta 1=0,000 ; \beta 32=0,553 ; \beta 43=-0,092 ; \beta 4=-0,080$ dan $\beta 5=$ 0,000 . Berdasarkan nilai konstanta dan koefisien regresi tersebut, maka hubungan antara variabel-variabel independen dengan variabel dependen dalam model regresi dapat dirumuskan sebagai berikut :

$$
Y=0,580+0,000 X_{1}+0,553 X_{2}-0,092 X_{3}+0,080 X_{4}+0,000 X_{5}
$$

Koefisien determinasi (Adjusted $R^{2}$ ) pada tabel 4. sebesar 0,297 yang berarti variabilitas dari variabel dependen dapat dijelaskan oleh variabilitas dari variabel independen sebesar $29,7 \%$, sedangkan sisanya $70,3 \%$ dijelaskan oleh variabel lainnya yang tidak diteliti atau tidak masuk dalam model regresi. Sehingga menunjukkan bahwa penggabungan variabel Curret Ratio (CR), Quick Ratio (QR), Debt to Equity Ratio (DER), Return On Assets (ROA) dan Pertumbuhan Penjualan (Sales Growth) tidak cukup relevan digunakan untuk memprediksi kebangkrutan (Z-Score Altman) pada perusahaan telekomunikasi dimasa yang akan datang. Dari hasil perhitungan F-test pada tabel 18 . diatas, nilai $F_{\text {hitung }}>F_{\text {tabel }}$ maka $\mathrm{H}_{0}$ ditolak dan menerima $\mathrm{H}_{8}$ yang berarti $\mathrm{X}_{1}(\mathrm{CR}), \mathrm{X}_{2}(\mathrm{QR}), \mathrm{X}_{3}(\mathrm{DER}), \mathrm{X}_{4}(\mathrm{ROA})$ dan $\mathrm{X}_{5}$ (Sales Growth) secara simultan berpengaruh terhadap $\mathrm{Y}$ (Z-Score Altman).

Uji t-test digunakan untuk mengetahui pengaruh masing-masing variabel independen terhadap variabel dependen. Nilai $\mathrm{t}(42: 0,05)$ di tabel statistik $\mathrm{t}$ adalah 2,021 , maka hasil pengujian hipotesis pada setiap variabel independen antara lain :

\section{Current Ratio Tidak Berpengaruh Signifikan Terhadap Financial Distress}

Rasio ini digunakan untuk mengukur kemampuan perusahaan dalam membayar kewajiban lancarnya dengan menggunakan aset lancar yang dimiliki perusahaan. Dari hasil pengukuran rasio, apabila hasil rasio ini rendah menandakan perusahaan kurang modal untuk membayar kewajibannya. Namun apabila hasil rasio ini tinggi belum tentu kondisi perusahaan sedang baik karena kas tidak digunakan sebaik mungkin. Menurut Kasmir (2013:135) seringkali dipakai bahwa rasio lancar dengan standar 200\% (2:1) dianggap sebagai ukuran yang cukup baik bagi perusahaan, artinya setiap 1 rupiah hutang lancar sudah tercover oleh 2 rupiah aktiva lancar.

Berdasarkan hasil pengolahan data sebelumnya, dapat dibuktikan bahwa hipotesis $1\left(\mathrm{H}_{1}\right)$ yang menyatakan CR tidak mempunyai berpengaruh signifikan terhadap kondisi financial distress perusahaan subsektor pulp dan kertas tahun 2012-2017 dengan model Altman z-score. Karena dari hasil pengujian secara parsial (uji t) tidak terdapat pengaruh signifikan secara parsial antara perubahan variabel CR terhadap Altman Z-Score. Perusahaan yang kurang likuid 
memiliki resiko yang besar yang berakibat pada macetnya pelunasan kewajiban lancarnya dan pembiayaan atas aktivitas perusahaan.

Pada output SPSS menunjukkan variabel CR mempunyai nilai beta unstandardized coefficient sebesar 0,000. Berdasarkan hasil tersebut dapat dikatakan bahwa variabel CR tidak mempunyai pengaruh yang positif terhadap Altman Z-Score. Hasil ini sejalan dengan hasil penelitian yang dilakukan oleh (Setiawan 2009) mengatakan current ratio tidak berpengaruh terhadap kondisi financial distress perusahaan. Sedangkan (Haq 2013) mengatakan Curent ratio berpengaruh terhadap kemungkinan terjadinya financial distress pada perusahaan yang terdaftar di BEl.

\section{Quick Ratio Tidak Berpengaruh Signifikan Terhadap Financial Distress}

Quick ratio merupakan ukuran kemampuan perusahaan dalam memenuhi jangka pendeknya dengan tidak menghitungkan persediaan, karena persediaan biasanya dianggap merupakan aset yang tidak likuid. Quick ratio disebut juga acid test ratio, merupakan pertimbangan antara jumlah aktiva lancar dikurangi persediaan, dengan jumlah hutang lancar. Persediaan tidak dimasukkan dalam perhitungan quick ratio karena persediaan merupakan komponen aktiva lancar yang paling kecil tingkat likuiditasnya. Berdasarkan hasil pengolahan data sebelumnya, dapat dibuktikan bahwa hipotesis $2(\mathrm{H} 2)$ yang menyatakan QR tidak mempunyai berpengaruh signifikan terhadap kondisi financial distress perusahaan subsektor pulp dan kertas tahun 2012-2017 dengan model Altman z-score. Karena dari hasil pengujian secara parsial (uji t) tidak terdapat pengaruh signifikan secara parsial antara perubahan variabel QR terhadap Altman Z-Score.

Pada output SPSS menunjukkan variabel QR mempunyai nilai beta unstandardized coefficient sebesar 0,553. Berdasarkan hasil tersebut dapat dikatakan bahwa variabel QR tidak mempunyai pengaruh yang positif terhadap Altman Z-Score. Hasil penelitian ini sejalan dengan hasil penelitian yang dilakukan oleh peneliti terdahulu yaitu Setiawan (2009) yang mengatakan bahwa quick ratio berpengaruh negatif terhadap kondisi financial distress perusahaan.

\section{Debt to Equity Ratio Tidak Berpengaruh Signifikan Terhadap Financial Distress}

Debt to Equity Ratio merupakan salah satu rasio keuangan yang tergolong kelompok rasio solvabilitas. Debt to Equity Ratio adalah rasio yang menggunakan hutang dan modal untuk mengukur besarnya rasio. Debt to Equity Ratio merupakan rasio yang dipergunakan untuk mengukur tingkat penggunaan utang terhadap total shareholder's equity yang dimiliki perusahaan. Debt to Equity Ratio menunjukan persentase penyediaan dana oleh pemegang saham terhadap pemberi pinjaman. Semakin tinggi rasio, semakin rendah pendanaan perusahaan yang disediakan oleh pemegang saham.

Berdasarkan hasil pengolahan data sebelumnya, dapat dibuktikan bahwa hipotesis 3 (H3) yang menyatakan DERtidak mempunyai berpengaruh signifikan terhadap kondisi financial distress perusahaan subsektor pulp dan kertas tahun 2012-2017 dengan model Altman z-score. Karena dari hasil pengujian secara parsial (uji t) tidak terdapat pengaruh signifikan secara parsial antara perubahan variabel QR terhadap Altman Z-Score. Pada output SPSS menunjukkan variabel DER mempunyai nilai beta unstandardized coefficient sebesar $-0,092$. Berdasarkan hasil tersebut dapat dikatakan bahwa variabel DER tidak mempunyai pengaruh yang positif terhadap Altman Z-Score.

Penelitian yang dilakukan oleh Iman dan Srengga (2012) yang menunjukkan bahwa Debt To Equity tidak berpengaruh signifikan terhadap kondisi financial distress, namun hal ini bertolak belakang dengan penelitian yang dilakukan oleh Simanjuntak, Titik, dan Aminah 
(2017) yang menunjukkan bahwa Debt To Equity mempunyai pengaruh signifikan terhadap kondisi financial distress. Penelitian yang dilakukan oleh Iman dan Srengga (2012) sejalan dengan penelitian yang dilakukan saat ini bahwa variabel Debt to Equity Ratio tidak berpengaruh signifikan terhadap kondisi financial distress perusahaanpulpdan kertas yang terdaftar di Bursa Efek Indonesia tahun2012 -2017 dengan model Altman Z-Score.

\section{Return On Asset Berpengaruh Signifikan Terhadap Financial Distress}

Return On Asset adalah rasio profitabilitas yang menunjukan persentase keuntungan (laba bersih) yang diperoleh perusahaan sehubungan dengan keseluruhan sumber daya atau rata-rata jumlah aset. Dengan kata lain, Return on Assetatau sering disingkat dengan ROA adalah rasio yang mengukur seberapa efisien suatu perusahaan dalam mengelola asetnya untuk menghasilkan laba selama suatu periode.

Rasio ROA dapat membantu manajemen dan investor untuk melihat seberapa baik suatu perusahaan mampu mengkonversi investasinya pada aset menjadi keuntungan atau laba (profit). Semakin tinggi hasil ROA suatu perusahaan mencerminkan bahwa semakin baik penggunaan aset yang dilakukan perusahaan untuk menghasilkan laba, dan resiko perusahaan untuk mengalami financial distress akan berkurang atau semakin kecil.

Berdasarkan hasil pengolahan data sebelumnya, dapat dibuktikan bahwa hipotesis 4 $\left(\mathrm{H}_{4}\right)$ yang menyatakan ROA mempunyai pengaruh signifikan terhadap kondisi financial distressperusahaan pulp dan kertas yang terdaftar di BEI diterima. Karena berdasarkan hasil perhitungan uji secara parsial diperoleh terdapat pengaruh signifikan secara parsial antara perubahan variabel ROA terhadap Altman Z-Score. Semakin tinggi ROA maka akan semakin besar juga tingkat return/payback yang diterima oleh perusahaan. ROA sangat berguna bagi manajemen perusahaan dalam melakukan pengelolaan aktivitas operasi dalam perusahaan.

Berpengaruhnya variabel ROA terhadap kondisi financial distress perusahaan pulp dan kertas di BEI dapat dibuktikan dari analisis deskriptif dimana PT. Alkindo Naratama Tbk. yang diprediksi memiliki tingkat kebangkrutan yang rendah, memiliki rasio ROA yang paling besar yang dapat diasumsikan perusahaan memiliki rasio profitabilitas yang baik. Sedangkan PT. Kertas Basuki Rachmat Indonesia Tbk. yang diprediksi memiliki tingkat kebangkrutan yang tinggi, memiliki rasio ROA yang paling sedikit yang diasumsikan perusahaan memiliki rasio profitabilitas yang paling buruk. Dari hasil penelitian ini, dapat disimpulkan rasio ROA berhubungan dengan financial distress sehingga rasio ini dapat digunakan untuk mengukur tingkat kebangkrutan perusahaan.

Output SPSS menunjukkan variabel ROA mempunyai nilai beta unstandardized coefficient sebesar 0,080. Berdasarkan hasil tersebut dapat dikatakan bahwa ROA mempunyai pengaruh yang positif terhadap Altman Z-Score. Dimana dapat diartikan semakin besar rasio ROA maka semakin meningkat pula nilai Altman Z-Score atau dapat dikatakan semakin berkurangnya resiko kebangkrutan perusahaan.

Hasil penelitian ini mendukung penelitian Indriyati (2010) yang menyimpulkan bahwa variabel ROA mempunyai pengaruh signifikan terhadap Altman Z-Score.Dan menurut Furqon (2012) mengatakan return on asset dapat digunakan untuk memprediksi terjadinya kondisi financial distress perusahaan. Penelitian sebelumnya sejalan dengan penelitian yang dilakukan saat ini bahwa variabel Return On Assetsberpengaruhterhadap Kondisi Financial Distress perusahaan.

\section{Sales Growth Tidak Berpengaruh Signifikan Terhadap Financial Distress}

Pertumbuhan penjualan mencerminkan keberhasilan investasi periode masa lalu dan dapat dijadikan sebagai prediksi pertumbuhan dimasa yang akan datang. Pertumbuhan penjualan merupakan indikator permintaan dan daya saing perusahaan dalam suatu industri. Menurut Kesuma(2009) juga menyatakan bahwa sales growth adalah kenaikan jumlah 
penjualan dari tahun ketahun atau dari waktu ke waktu. Pertumbuhan penjualan tinggi, maka akan mencerminkan pendapatan perusahaan yang juga meningkat.

Berdasarkan hasil pengolahan data sebelumnya, dapat dibuktikan bahwa hipotesis 5 (H5) yang menyatakan variabel sales growth pada perusahaan subsektor pulp dan kertas yang terdaftar di BEI ditolak. Karena dari hasil pengujian secara parsial diperoleh tidak terdapat pengaruh signifikan secara parsial antara variabel sales growth terhadap Altman Z-Score.

Pada output SPSS menunjukkan variabel sales growth mempunyai nilai beta unstandardized coefficient sebesar 0,000. Berdasarkan hasil tersebut dapat dikatakan bahwa variabel sales growth tidak mempunyai pengaruh yang positif terhadap Altman Z-Score.

Penelitian yang dilakukan oleh Widarjo dan Setiawan (2009) menyatakan bahwa sales growth tidakberpengaruh terhadap financial distress perusahaan. Berbeda dengan hasil penelitian yang dilakukan oleh Furqon (2012) bahwa sales growth dapat digunakan untuk memprediksi terjadinya kondisi financial distress perusahaan. Hasil penelitian ini sejalan dengan penelitian yang dilakukan oleh Setiawan (2009) bahwa sales growth tidak berpengaruh signifikan terhadap kondisi financial distress perusahaanpulpdan kertas yang terdaftar di Bursa Efek Indonesia tahun2012 -2017 dengan model Altman Z-Score.

\section{PENUTUP}

Berdasarkan analisis data dan pembahasan dari hipotesis yang telah disusun dan diuji pada bagian sebelumnya, maka dapat disimpulkan kinerja perusahaan Pulp dan Kertas berdasarkan analisis rasio likuiditas rata-rata kurang baik. Karena dari rata-rata rasio Current Ratio (CR) dan rasio Quick Ratio (QR) relatif rendah dari rata -rata CR dan QR yang bagus. Karena dari rata-rata rasio Current Ratio (CR) dan rasio Quick Ratio (QR) relatif rendah dari rata -rata CR dan QR yang bagus. Hampir seluruh perusahaan telekomunikasi diprediksi mengalami kebangkrutan Hanya PT. Alkindo NaratamaTbk. Dan PT. Kedawung Setia Industrial Tbk. yang terindikasi tidak mengalami financial distress. PT. Kertas Basuki Rachmat Tbk. memiliki nilai ZScore terburuk diantara sampel perusahaan pulp dan kertas yang digunakan dalam penelitian.

Current Ratio tidak berpengaruh terhadap Terhadap Kondisi Financial Distress. Hal ini karena konsisten nilai Current Ratio Kondisi Financial Distress yang dimiliki suatu perusahaan sehingga tidak berpengaruh terhadap Terhadap Kondisi Financial Distress.jika CR terlalu besar akan menimbulkan masalah pada perusahaan. Dimana CR juga belum tentu menjamin akan terbayarnya hutang perusahaan yang sudah jatuh tempo dikarenakan proporsi atau distribusi dari aktiva lancar tidak menguntungkan misalnya dalam aset lancar terdapat jumlah persediaan yang relatif tinggi dibandingkan dengan jumlah penjualannya sehingga terjadi kendala pada perputaran persediaan yang rendah dan menunjukkan adanya over investment pada persediaan.

Quick Ratio tidak berpengaruh terhadap Kondisi Financial Distress hal ini disebabkan oleh kemampuan perusahaan dalam memenuhi kewajiban jangka pendeknya dengan tidak memperhitungkan persediaan berpengaruh terhadapKondisi Financial Distress. Quick ratio disebut juga acid test ratio, merupakan pertimbangan antara jumlah aktiva lancar dikurangi persediaan, dengan jumlah hutang lancar. Persediaan tidak dimasukkan dalam perhitungan quick ratio karena persediaan merupakan komponen aktiva lancar yang paling kecil tingkat likuiditasnya.

Debt to Equity Ratio tidak berpengaruh terhadap kondisi Financial Distress. Hal ini berarti kemampuan modal sendiri perusahaan tersebut untuk memenuhi seluruh kewajiban tidak berpengaruh terhadap kondisi Financial Distress. Debt to Equity Ratio menunjukan persentase penyediaan dana oleh pemegang saham terhadap pemberi pinjaman. Semakin tinggi rasio, semakin rendah pendanaan perusahaan yang disediakan oleh pemegang saham.

Return On Asset berpengaruh terhadap kondisi Financial Distress. Hal ini mengukur seberapa efisien suatu perusahaan dalam mengelola asetnya untuk menghasilkan laba selama 
suatu periode tidak berpengaruh terhadap pergerakan kondisi Financial Distress. Besarnya ROA mencerminkan pengembalian perusahaan dari seluruh aktiva yang diberikan oleh perusahaan sehingga nilai ROA penting bagi manajemen perusahaan untuk menilai kinerja perusahaan.

Sales Growth tidak berpengaruh terhadap kondisi Financial Distress. Hal ini berarti kemampuan perusahaan dalam rangka mempertahankan posisi ekonominya dalam pertumbuhan perekonomian dan dalam industri atau pasar produk tempatnya beroperasi tidak berpengaruh terhadap kondisi Financial Distress.

Dalam penelitian ini ada keterbatasan yang dapat menghambat hasil penelitian sesuai dengan hipotesis yang diajukan oleh peneliti. Adapun keterbatasan penelitian tersebut adalah dimana penelitian hanya dilakukan pada salah satu sektor perusahaan yang terdaftar di Bursa Efek Indonesiayaitu di perusahaan pulp dan kertas yang terdaftar di Bursa Efek Indonesia tahun 2012-2017.Keterbatasan dalam variabel penelitian, dimana dalam penelitian ini hanya meneliti variabel Current Ratio (CR), Quick Ratio (QR), Debt to Equity (DER), Return On Assets (ROA), dan Sales Growth.

Setelah mengkaji hasil penelitian ini maka implikasi manajerial yang dapat penulis ajukan bagi perusahaan pulp dan kertas yang memiliki rasio likuiditas yang kurang baik dan beberapa kekurangan dari hasil penelitian ini. Maka, Bagi peneliti sebelumnya, agar pada penelitian selanjutnya sampel yang digunakan diperluas, mencakup seluruh sektor yang ada di Bursa Efek Indonesia. Penelitian sebelumnya juga disarankan hendaknya lebih mempertimbangkan lagi rasio - rasio lainnya yang dapat mempengaruhi kondisi Financial Distress.Bagi pihak manajemen perusahaan, diharapkan dapat meningkatkan kinerja keuangan setiap tahunnya sehingga persepsi investor terhadap prospek kinerja keuangan perusahaan dimasa yang akan datang dapat dijaga dengan baik.Bagi investor, walaupun pada penelitian ini ada yang terbukti tidak berpengaruh signifikan terhadap financial distress, tetap saja investor tidak boleh mengabaikan vaiabel CR, QR, DER, ROA, dan SalesGrowth ketika melakukan investasi. Karna seperti CR hasilnya tidak berpengaruh signifikan, berarti perusahaan harus memperhatikan lagi kebutuhan jumlah modal kerja dimasa mendatang dan kemungkinan perubahan dari nilai aktiva lancar.

\section{DAFTAR RUJUKAN}

Adisasmita, Rahardjo. (2008). Pengembangan Wilayah Konsep dan Teori. Penerbit Graha Ilmu. Jakarta.

Furqon Reno,Kusumawardana dan Aisyah, Siti. (2012). Analisis Laporan Keuangan Untuk Memprediksi Financial Distress.

Furqon. (2012). Analisis Rasio Keuangan Untuk Memprediksi Financial Distress (Studi Pada Indeks LQ45 Yang Terdaftar di Bursa Efek Indonesia Periode 2009-2011).

Fahmi,Irham. (2011). Analisis Laporan Keuangan Lampulo : ALFABETA.

Ghozali, Imam. (2009). Aplikasi Analisis Multivariate Dengan Program SPSS, Edisi Keempat. Penerbit Universitas Diponegoro. Jakarta.

Harahap, Sofyan Syafri. (2013). Analisis Kritis Atas Laporan Keuangan, Edisi Kesebelas, Rajawali Pers, Jakarta.

Harahap.(2007). Analisis Kritis Atas Laporan Keuangan, edisi pertama, cetakan ketiga, Penerbit : Raja Grafindo Persada, Jakarta

Hapsari. (2012) . Kekuatan Rasio Keuangan Dalam Memprediksi Kondisi Financial Distress Perusahaan Manufaktur Periode 2007-2010.

Haq. (2013). Analisis Rasio Keuangan Dalam Memprediksi Financial Distress (studi pada perusahaan manufaktur yang terdaftar di Bursa Efek Indonesia). 
Indri, Evanny Hapsari. (2012) .Kekuatan Rasio Keuangan dalam Memprediksi Kondisi Financial Distress Perusahaan Manufaktur di BEI.

Imam, Mas'ud dan Srengga, Reva Maymi. (2012). Analisis Rasio Keuangan Untuk Memprediksi Kondisi Financial Distress Perusahaan Manufaktur.

Indriyati, Irma Thisca. (2010). Analisis Laporan Keuangan dan Penggunaan Z-Score Altman untuk Memprediksi Tingkat Kebangkrutan Perusahaan Properti yang Terdaftar di Bursa Efek Indonesia periode 2006-2008. Thesis. Fakultas Ekonomi Universitas Sebelas Maret. Surakarta. (https://eprints.uns.ac.id/3968/)

Kasmir. (2008). Analisis Laporan Keuangan,edisi pertama, cetakan pertama, penerbit:sansu Moto, Jakarta.

Lukviarman. (2009). Perbandingan Analisis Prediksi Kebangkrutan Menggunakan Model Altman Pertama, Altman Revisi, dan Altman Modifikasi Dengan Ukuran dan Umur Perusahaan Sebagai Variabel Penjelas (Studi Pada PerusahaanManufaktur Yang Terdaftardi Bursa Efek Indonesia) .

Madura, Jeff. (2007). Pengantar Bisnis, Edisi Empat, Terjemahan. Penerbit Salemba Empat. Jakarta.

Ross S.A, Westerfield R.W. \& Jordan,B.D. (2008). Fundamentals Of Corporate Finance, New York: Mc Graw-Hill.

Susanti. (2013). Analisis Laporan Keuangan, Liberty,Yogyakarta

Suciati Dini. (2008). Prediksi Kondisi Financial Distress Kredit Pemilikan Motor, Skripsi, Universitas Indonesia,Jakarta.

Simanjuntak Christon, Farida Titik Kristanti, Wiwin Aminah (2017). Pengaruh Rasio Keuangan Terhadap Kondisi Financial Distress (Studi Pada Perusahaan Transportasi Yang Terdaftar di BEI. E-Proceeding of management : Volume 4 Nomor 2 Agustus 2017.

Widarjo dan Setiawan . (2009) . Pengaruh Rasio Keuangan Terhadap Kondisi Financial Distress Perusahaan Otomotif. 